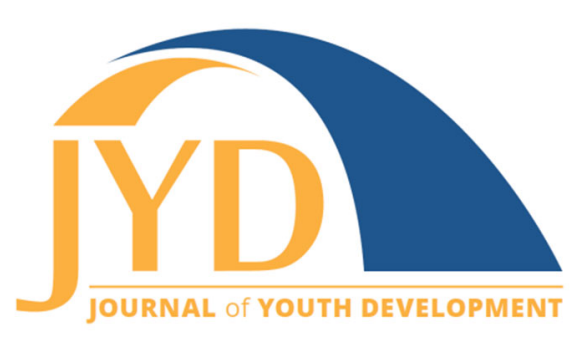

http://jyd.pitt.edu/ | Vol. 15 Issue 5 DOI 10.5195/jyd.2020.823 | ISSN 2325-4017 (online)

\title{
4-H STEM Curriculum Challenges: A Delphi Study
}

\author{
Hannah Branscum \\ Oklahoma State University, 4-H Youth Development \\ hmbranscum@gmail.com \\ Jeff Sallee \\ Oklahoma State University, 4-H Youth Development \\ jeff.sallee@okstate.edu
}

\section{Kevin Allen}

Oklahoma State University, Natural Resources, Ecology, and Management

kevin.allen@okstate.edu

\author{
Marshall A. Baker \\ Collegiate Edu-Nation \\ mbakerelt@gmail.com
}

\section{Samantha Blackwell}

Oklahoma State University, Agricultural Education, Communications, and Leadership

samantha.warner@okstate.edu

\begin{abstract}
Science, technology, engineering and math (STEM) skills have become essential for today's youth. STEMliterate individuals are a necessity to fill the ever-growing STEM employment pipeline. Employers are expecting applicants with STEM skills. 4-H programs across the nation have recognized the importance of educating STEM-minded youth. As STEM programs become more prevalent within 4-H, it is essential to address challenges Extension educators and 4- $H$ volunteers face when teaching STEM curriculum. In this study the Delphi technique was utilized to collect the opinions of a geographically dispersed group of 4-H Extension educators and volunteers. Each group served on a separate panel and were asked the question, "What challenges do you face when teaching STEM curriculum?" After 3 rounds of study, both the educator and volunteer panels identified 2 challenges faced when teaching STEM curriculum. Through identification of these challenges, Oklahoma state 4-H staff can better address the professional development needs of educators and volunteers within the organization, and support the desired scientific literacy outcomes of 4-H youth.
\end{abstract}

Key words: STEM, curriculum, Delphi, challenges

(cc) EY New articles in this journal are licensed under a Creative Commons Attribution 4.0 License. This journal is published by the University Library System, University of Pittsburgh and is cosponsored by the University of Pittsburgh Press. The Journal of Youth Development is the official peer-reviewed publication of the National Association of Extension 4-H Youth Development Professionals and the National AfterSchool Association. 


\section{Introduction}

\section{Background}

Scientific literacy is essential for youth success in the $21^{\text {st }}$ century (National Science Board, 2018). Employers are searching for scientifically literate young people to fill the STEM (Science, Technology, Engineering, and Math) pipeline (U.S. Department of Commerce, 2017). According to the National Science Board (2018), the number of jobs requiring extensive STEM abilities has increased by $34 \%$ in the last 10 years. However, little research exists on preparation of educators and volunteers to teach science curricula; it is imperative to identify these challenges to ultimately improve scientific literacy of youth (Smith \& Schmitt-McQuitty, 2013).

The need for STEM education is being addressed by government agencies, private entities, school systems, and non-formal educational settings, such as 4-H (Cafarella et al., 2017; National Academy of Science, 1996; Shafer, 2015; Turnbull et al., 2013; The White House, 2017). These agencies and organizations recognize the importance of STEM education and are striving to create a scientifically literate society and provide youth with the knowledge and skills needed to succeed in $21^{\text {st }}$ century life (4-H National Headquarters, 2011; Rice et al., 2016). Non-formal education organizations are providing additional avenues to expand this knowledge and peak science interest (Kahler \& Valentine, 2011; Kisiel, 2006).

In 2006, an initiative was introduced by National 4- $\mathrm{H}$ Headquarters and the National 4-H Council to increase and improve STEM programming within 4-H (Turnbull et al., 2013). By 2012, 1.33 million new youth had been reached with $4-\mathrm{H}$ science programming due to the direct impact of the 4-H Science Initiative (Noyce Foundation, 2013). Through this initiative, pedagogical methods of science instruction were examined to determine their effectiveness in increasing youth engagement and knowledge (Turnbull et al., 2013).

While the implementation of STEM programming has been positive, retention of 4- $\mathrm{H}$ Extension educators to carry out the programming is an ongoing issue (Harder et al., 2014; Safrit \& Owen, 2010; Vines et al., 2018). Safrit and Owen (2010) found training is an important aspect of job satisfaction and retention of $4-\mathrm{H}$ Extension educators..

Additionally, 4-H programs rely on volunteers to ensure the success and impact of 4- $\mathrm{H}$ programs in promotion of positive youth development (Alexander \& Freel, 2018; Pleskac, 2009; Sinasky \& Bruce, 2007). Numerous researchers found volunteers are motivated for a variety of reasons and it is also important to address their motivation and retention as it relates to the $4-\mathrm{H}$ 


\section{4-H STEM Curriculum Challenges: A Delphi Study}

program (Alexander \& Freel, 2018; Cleveland \& Thompson, 2007; Culp \& Schwartz, 1999a; Terry et al., 2013; Worker, 2016). With an established need for both 4-H Extension educator and volunteer training in STEM topics, the awareness of instructional methods of STEM education can help guide professional development and increase student learning (Astroth, 2007; Haugen et al., 2016; Safrit \& Owen, 2010).

\section{Problem and Purpose}

To address scientific literacy within the Oklahoma 4-H program, 4-H State program specialists must first become aware of the challenges faced by 4-H educators and volunteers when teaching STEM curriculum. By addressing the needs of those presenting the curriculum to youth, more efficient methods of promoting scientific literacy can be implemented. This study utilized the Delphi technique to determine the perceived challenges faced by highly qualified 4-H volunteers and Cooperative Extension educators when teaching STEM curriculum to Oklahoma 4-H youth.

\section{Methodology}

\section{Delphi Method}

The Delphi technique was the methodology selected for this study. Within the realm of education, the Delphi method has been utilized for varying purposes including curriculum development, evaluation, and identification of program barriers (Martin \& Frick, 1998). Delphi studies allow for the collection of opinions from numerous experts within a field, despite geographic separation (Hsu \& Sandford, 2007; Mayfield et al., 2005; Sitlington \& Coetzer, 2014). Structured, anonymous commentary is provided by the experts to gather consensus of opinion regarding a topic or issue (Brady, 2015). Questionnaires are sent to a panel of experts with information and results being presented to panel members between each round (Hanfin, 2004). Through this iteration process panelists can examine and clarify their ideas (Dalkey et al., 1972; Hsu \& Sandford, 2007). Delphi methodology combines both quantitative and qualitative data to inform practice within an organization (Ludwig, 1997).

The study utilized a 3-round Delphi conference approach and included two panels of experts, so items meeting consensus after three rounds could be compared ( Ramsey, 2009; Young et al., 2019). Two populations were of interest this study: Oklahoma Cooperative Extension educators and Oklahoma 4-H volunteers. Purposive samples of each population were proportionally stratified based on geographic location, ensuring equal representation of the four Oklahoma 


\section{4-H STEM Curriculum Challenges: A Delphi Study}

Cooperative Extension districts: Northeast, Southeast, Northwest, and Southwest (Johnson \& Christensen, 2014, Saucier et al., 2012).

\section{Panel Selection}

The first panel consisted of volunteers who met the following two characteristics:

1. Volunteer panelists should currently be serving, or have served within the past 5 years, on the Oklahoma 4-H Volunteer Board. The board is a group of certified and elected 4-H volunteers who assist and support Oklahoma 4-H state staff educational programming and development (Oklahoma 4-H, 2017).

2. Volunteer panelists must be tenured, meaning they have served 5 or more years in their role with 4-H (Culp \& Schwartz, 1999b).

The second panel consisted of Oklahoma Cooperative Extension educators nominated by their respective $4-\mathrm{H}$ district program specialists (DPSs) to serve on the second panel. The nominations followed the recommendation of Hsu and Sandford (2007) to receive nominations from well-known and respected leaders. The DPSs were asked to recommend educators they deemed "expert" in the area of 4-H youth development, with a minimum 50\%-time 4-H appointment in the Oklahoma Cooperative Extension system.

\section{Instrument Development and Data Collection}

A personalized email (Dillman et al., 2014) was sent to seven volunteers and seven nominated educators from each of the four districts (a total of 28 for each panel), requesting their participation in the study. The email included an internet survey link to the first-round questionnaire. The first questionnaire was composed of demographic questions and the openended question, "What challenges do you face when teaching STEM curriculum?" Demographic questions included district association, years served in respective roles, gender, race/ethnicity, education attained, and whether or not formal or non-formal training had been received in science. Fourteen volunteers (50\%) and 22 educators (79\%) completed their respective firstround questionnaires.

Upon receiving first-round responses challenge statements were developed. To generate the challenge statements presented in Round 2, a thematic analysis was completed on responses to the open-ended question for both panels (Johnson \& Christensen, 2014. Participant responses were examined for duplicate wording and ideas, along with compound statements that would need to be separated (Ramsey, 2009; Shinn et al., 2009). Inductive codes were utilized (Johnson \& Christensen, 2014). Statements were divided into meaningful analytical units 


\section{4-H STEM Curriculum Challenges: A Delphi Study}

(Johnson \& Christensen, 2014; Rubin et al., 2009) and hand-coded to identify concepts within the qualitative data set. To ensure intercoder reliability, an additional researcher coded the data independently (Johnson \& Christensen, 2014). Results were shared and common themes developed into the challenge statements presented to each panel.

Challenge statements were sent to panelists in a Round-2 questionnaire. The thematic analysis was also included to ensure the researchers captured the participant's perspectives correctly (Fletcher \& Marchildon, 2014; Hsu \& Sanford, 2007; Ludwig, 1997; Sitlington \& Coetzer, 2014). Panelists were asked to indicate their agreement with each challenge statement on a 6-point Likert-type scale: 1 (strongly disagree), 2 (disagree), 3 (slightly disagree), 4 (slightly agree), 5 (agree), and 6 (strongly agree). This response scale follows other agricultural education professionals who have used Delphi methodology for social sciences research (Ramsey, 2009; Shinn, et al., 2009; Siegfried, 2011). A comment box was provided with each challenge statement, allowing participants to clarify ideas or offer justification for responses (Hsu \& Sandford, 2007; Ludwig, 1997). Any comments provided were used by researchers in data analysis. Eight volunteers (29\%) and 13 educators (46\%) completed Round 2.

Ludwig (1997) suggests having a predetermined level of consensus for Delphi studies. For our study, an a-priori decision was made: If $75 \%$ of each panel ranked an item 5 or 6 then the statement would meet consensus and be removed from further study. Items receiving less than $75 \%$ agreement, but more than $51 \%$ agreement, were sent in a Round 3 questionnaire. Items receiving less than $51 \%$ agreement did not meet consensus and were removed from further examination (Ramsey, 2009; Shinn, et al., 2009; Siegfried, 2011).

Completion of the second-round questionnaire prompted an invitation to participate in the thirdround questionnaires. Challenge statements not reaching consensus in Round 2 but reached agreement of $51-74 \%$ were included. Panelists were asked to rank their agreement with these challenge statements for a final time. Anonymous feedback from Round 2 was included for participants to examine (Fletcher \& Marchildon, 2014; Ludwig, 1997). A comment box was also provided with each challenge statement, allowing participants to clarify ideas or offer justification for responses (Hsu \& Sandford, 2007; Ludwig, 1997). Any comments provided were used by researchers in data analysis. Seven volunteers (25\%) and 13 educators (46\%) completed Round 3. 


\section{Findings and Discussion}

\section{Round 1}

Round 1 of this study sought to understand the perceived STEM curriculum challenges within Oklahoma 4-H by an expert panel of tenured volunteers and an expert panel of educators. Survey responses are shown here.

\section{Volunteer panel $(\boldsymbol{N}=\mathbf{1 4})$}

- Funding for supplies/equipment

- Accessing resources/supplies/equipment

- Lacking confidence in STEM subject matter

- Lacking knowledge of available curriculum

- Lacking parental support

- Making STEM curriculum appropriate for wide age ranges

- Establishing an interested youth audience

- Competing with other activities for youths' time

- Associating the name STEM with subject difficulty

- Curriculum design is too structured

- Receiving help from parents/community members

- Rural location limiting access to training

- Youth prefer quick experiments

\section{Educator panel $(\boldsymbol{N}=\mathbf{2 2})$}

- Funding for supplies/equipment

- Accessing resources/supplies/equipment

- Feeling adequately trained

- Lacking time in schedule for STEM education

- Lacking confidence in STEM subject matter

- Lacking knowledge of subject matter

- Making STEM curriculum applicable to youth

- Making STEM curriculum engaging to youth

- Making STEM curriculum appropriate for wide age ranges

- Establishing an interested youth audience

- Youth associating the name STEM with subject difficulty

- Competing with other activities for youths' time

- Communicating with schoolteachers

- Enabling volunteers to use STEM curriculum at a club level

Equipment, training, time management, funding, confidence, and dissatisfaction with current curriculum design were common challenges the panelists identified. One volunteer panelist mentioned, "sometimes [there is] not enough time to do the subject justice, or enough 
materials for the class." Another stated, "money tends to be an issue." An educator stated, "the biggest challenge that I face when teaching STEM is being adequately trained on the kits that are made available to me." Another educator said, "I am often uncomfortable teaching STEM curriculum because I feel like I don't fully understand it."

\section{Round 2}

Panelists who completed Round 1 were sent questionnaires to complete Round 2 of the study. Through the questionnaire, each participant was asked to indicate their level of agreement with the challenge statements identified in the first round. The results are displayed in Table 1 and Table 2.

For our study: If $75 \%$ of our expert panelists rated an item 5 or 6 on the 6-point Likert-type scale, then the statement would meet consensus and be removed from further study. Items receiving less than $75 \%$ agreement, but more than $51 \%$ agreement, were sent to the next round. Items receiving less than $51 \%$ agreement did not meet consensus and were removed from further examination (Ramsey, 2009; Shinn, et al., 2009; Siegfried, 2011). This technique provided a predetermined a priori decision-making tool (Ludwig, 1997).

Table 1. Challenges Statements and Agreement Percentages in Round 2: Volunteer Panel $(\boldsymbol{N}=8)$

\begin{tabular}{|l|c|}
\hline Challenges faced when teaching STEM curriculum & \% Agreement \\
\hline Funding for supplies/equipment & 75.00 \\
\hline Competing with other activities for youths' time & 87.50 \\
\hline Accessing resources/supplies/equipment & 62.50 \\
\hline Lacking parental support & 62.50 \\
\hline Youth prefer quick experiments & 62.50 \\
\hline Lacking time in schedule for STEM education & 50.00 \\
\hline Lacking knowledge of available curriculum & 50.00 \\
\hline Establishing an interested youth audience & 50.00 \\
\hline Making STEM curriculum appropriate for wide age ranges & 37.50 \\
\hline Associating the name STEM with subject difficulty & 37.50 \\
\hline Lacking confidence in STEM subject matter & 25.00 \\
\hline Receiving help from parents/community members & 25.00 \\
\hline Curriculum design is too structured & 12.50 \\
\hline Rural location limiting access to training & 12.50 \\
\hline
\end{tabular}


Journal of Youth Development | http://jyd.pitt.edu/ | Vol. 15 Issue 5 DOI 10.5195/jyd.2020.823 4-H STEM Curriculum Challenges: A Delphi Study

Table 2. Challenges Statements and Agreement Percentages in Round 2: Educator Panel $(\boldsymbol{N}=13)$

\begin{tabular}{|l|c|}
\hline Challenges faced when teaching STEM curriculum & \% Agreement \\
\hline Feeling adequately trained & 75.00 \\
\hline Competing with other activities for youths' time & 75.00 \\
\hline Accessing resources/supplies & 61.54 \\
\hline Funding for supplies/equipment & 53.84 \\
\hline Making STEM curriculum appropriate for wide age ranges & 53.84 \\
\hline Youth associating the name STEM with subject difficulty & 53.84 \\
\hline Communicating with schoolteachers & 53.84 \\
\hline Enabling volunteers to use STEM curriculum at a club level & 53.84 \\
\hline Lacking confidence in subject matter & 50.00 \\
\hline Lacking time in schedule for STEM education & 46.15 \\
\hline Lacking knowledge of subject matter & 46.15 \\
\hline Making STEM curriculum applicable to youth & 38.46 \\
\hline Making STEM curriculum engaging to youth & 38.46 \\
\hline Establishing an interested youth audience & 38.46 \\
\hline
\end{tabular}

\section{Round 3}

Challenge statements reaching 51\%-74\% agreement in Round 2 were sent back to the panelists in the third round. This round sought to identify consensus on the remaining items. No challenge statements met consensus in this round (See Table 3 and Table 4).

Table 3. Challenges Statements and Agreement Percentages in Round 3: Volunteer Panel $(\boldsymbol{N}=7)$

\begin{tabular}{|l|c|}
\hline Challenges faced when teaching STEM curriculum & $\%$ Agreement \\
\hline Youth prefer quick experiments & 71.43 \\
\hline Accessing resources/supplies/equipment & 42.86 \\
\hline Lacking parental support & 42.86 \\
\hline
\end{tabular}


Table 4. Challenges Statements and Agreement Percentages in Round 2: Educator Panel $(N=13)$

\begin{tabular}{|l|c|}
\hline Challenges faced when teaching STEM curriculum & \% Agreement \\
\hline Accessing resources/supplies & 53.84 \\
\hline Making STEM curriculum appropriate for wide age ranges & 53.84 \\
\hline Communicating with schoolteachers & 53.84 \\
\hline Funding for supplies/equipment & 38.46 \\
\hline Enabling volunteers to use STEM curriculum at a club level & 38.46 \\
\hline Youth associating the name STEM with subject difficulty & 7.69 \\
\hline
\end{tabular}

\section{Panel Findings Comparison}

After three rounds of questionnaires, two challenge statements met consensus within each panel. Comparison of perceived challenges is presented in Table 5. Both panels reached consensus on the statement "competing with other activities for youths' time." The educator panel reached consensus on the statement "feeling adequately trained," and the volunteer panel reached consensus on the statement "funding for supplies/equipment."

Table 5. Comparison of Perceived Challenges Identified by 4-H Educator and 4-H Volunteer Panels

\begin{tabular}{|l|c|l|c|}
\hline $\begin{array}{l}\text { Challenges identified by } \\
\text { educators }\end{array}$ & $\begin{array}{c}\% \\
\text { Agreement }\end{array}$ & $\begin{array}{l}\text { Challenges identified by } \\
\text { volunteers }\end{array}$ & $\begin{array}{c}\% \\
\text { Agreement }\end{array}$ \\
\hline $\begin{array}{l}\text { Competing with other activities } \\
\text { for youths' time }\end{array}$ & 75.00 & $\begin{array}{l}\text { Competing with other activities for } \\
\text { youths' time }\end{array}$ & 75.00 \\
\hline Feeling adequately trained & 75.00 & Funding for supplies/equipment & 87.5 \\
\hline
\end{tabular}

The comparison of challenge statements not meeting consensus after three rounds are presented in Table 6. 
Journal of Youth Development | http://jyd.pitt.edu/ | Vol. 15 Issue 5 DOI 10.5195/jyd.2020.823 4-H STEM Curriculum Challenges: A Delphi Study

Table 6. Comparison of Perceived Challenges Identified by the Panels Not Reaching Consensus

\begin{tabular}{|c|c|c|c|}
\hline $\begin{array}{l}\text { Challenges identified by } \\
\text { educators }\end{array}$ & $\begin{array}{c}\% \\
\text { Agreement }\end{array}$ & $\begin{array}{l}\text { Challenges identified by } \\
\text { volunteers }\end{array}$ & $\begin{array}{c}\% \\
\text { Agreement }\end{array}$ \\
\hline Accessing resources/supplies & 53.84 & $\begin{array}{l}\text { Accessing } \\
\text { resources/supplies/equipment }\end{array}$ & 42.86 \\
\hline $\begin{array}{l}\text { Making STEM curriculum } \\
\text { appropriate for wide age ranges }\end{array}$ & 53.84 & $\begin{array}{l}\text { Making STEM curriculum } \\
\text { appropriate for wide age ranges }\end{array}$ & 37.50 \\
\hline $\begin{array}{l}\text { Lacking confidence in subject } \\
\text { matter }\end{array}$ & 50.00 & $\begin{array}{l}\text { Lacking confidence in STEM } \\
\text { subject matter }\end{array}$ & 25.00 \\
\hline $\begin{array}{l}\text { Lacking knowledge of subject } \\
\text { matter }\end{array}$ & 46.15 & $\begin{array}{l}\text { Lacking knowledge of available } \\
\text { curriculum }\end{array}$ & 50.00 \\
\hline $\begin{array}{l}\text { Lacking time in schedule for STEM } \\
\text { education }\end{array}$ & 46.15 & $\begin{array}{l}\text { Lacking time in schedule for } \\
\text { STEM education }\end{array}$ & 50.00 \\
\hline $\begin{array}{l}\text { Establishing an interested youth } \\
\text { audience }\end{array}$ & 38.46 & $\begin{array}{l}\text { Establishing an interested youth } \\
\text { audience }\end{array}$ & 50.00 \\
\hline $\begin{array}{l}\text { Youth associating the name STEM } \\
\text { with subject difficulty }\end{array}$ & 7.69 & $\begin{array}{l}\text { Associating the name STEM with } \\
\text { subject difficulty }\end{array}$ & 37.50 \\
\hline $\begin{array}{l}\text { Communicating with } \\
\text { schoolteachers }\end{array}$ & 53.84 & Youth prefer quick experiments & 71.43 \\
\hline $\begin{array}{l}\text { Enabling volunteers to use STEM } \\
\text { curriculum at a club level }\end{array}$ & 38.46 & Lacking parental support & 42.86 \\
\hline Funding for supplies/equipment & 38.46 & $\begin{array}{l}\text { Receiving help from } \\
\text { parents/community members }\end{array}$ & 25.00 \\
\hline $\begin{array}{l}\text { Making STEM curriculum applicable } \\
\text { to youth }\end{array}$ & 38.46 & $\begin{array}{l}\text { Curriculum design is too } \\
\text { structured }\end{array}$ & 12.50 \\
\hline $\begin{array}{l}\text { Making STEM curriculum engaging } \\
\text { to youth }\end{array}$ & 38.46 & $\begin{array}{l}\text { Rural location limiting access to } \\
\text { training }\end{array}$ & 12.50 \\
\hline
\end{tabular}

\section{Implications for STEM Curriculum}

The purpose of this study was to discover the challenges faced when teaching STEM curriculum by selected tenured 4-H volunteers and Cooperative Extension 4-H Educators. Between the two panels, three challenges were identified, which impact teaching of STEM curriculum:

1. Funding for supplies/equipment 


\section{4-H STEM Curriculum Challenges: A Delphi Study}

2. Competing with other activities for youths' time

3. Feeling adequately trained

\section{Funding for Supplies/Equipment}

Funding for Oklahoma Extension has decreased drastically in the past 7 years (27\%) according to Trapp (2017). This has led to changes in staffing structure, which will continue to affect Extension within the state. Volunteers may not be able to offset personal expenditures for supplies and other items used for their $4-\mathrm{H}$ activities. Without additional funding, STEM programming could be impaired. If club leaders struggle to provide the materials necessary to implement STEM curriculum, and counties or state staff are not in a financial position to assist, STEM programming will be set aside for more affordable and easily accessed curriculum.

During times of financial stress, it is imperative organizations demonstrate their impact to stakeholders (O’Neill, 1998; Workman \& Scheer, 2012). As a public program, Extension relies on outside sources to provide funding, and must prove to university administrators, taxpayers, and legislators it is worth the investment (O'Neill, 1998). With diminishing funding, documentation of 4-H's impact in the counties and state is vital to receiving recognition and funding for the sake of positive youth development (Workman \& Scheer, 2012). Historic data and solitary success stories, while worthwhile, are not enough to convince stakeholders in modern society to provide funding. If at all possible, dollar amounts and other economic impact data should be collected (O'Neill, 1998).

\section{Feeling Adequately Trained}

Training is essential for educators to increase scientific knowledge. Finding time to attend training and having sufficient funds to do so have been reported as obstacles in receiving science training (Riley \& Butler, 2012; Turnbull et al., 2013). However, many educators lack competence and confidence in science subject matter; therefore, it is crucial to provide quality training (Haugen et al., 2016; Turnbull et al., 2013). Though lack of confidence in STEM subject matter did not reach consensus with the educator panel, it is still worth considering in the context of feeling adequately trained. Without proper training, educators may not teach STEM curriculum due to lack of confidence and understanding.

In Oklahoma, 4-H state staff provide a minimum of five science in-service training sessions per year. Findings from this study indicate state Extension staff should look at ways to address the needs of county 4-H educators more accurately (Sinasky \& Bruce, 2007). Numerous educators 


\section{4-H STEM Curriculum Challenges: A Delphi Study}

commented on feeling confident in teaching the STEM workshops covered in professional development trainings, but they did not know how to proceed with science curriculum on their own. Specific content should be covered within these professional development sessions; however, additional time should be spent on pedagogical practices and learning strategies that can aid in youth engagement and educator understanding (Haugen et al., 2016).

\section{Competing With Other Activities for Youths' Time}

Competition with other activities is not a new phenomenon to 4-H member retention (Albright \& Ferrari, 2010; Astroth, 1985; Harder et al., 2005; Meeks-Baney \& Jones, 2013). This is recognized as a challenge by both the volunteer and educator panels. As youth get older, time conflicts can arise with jobs and other out-of-school organizations such as organized sports (Albright \& Ferrari, 2010; Harder et al., 2005). Meeks-Baney and Jones (2013) contend youth want to participate in organizations meeting their needs for affiliation (relationships) and achievement (recognition). Youth also want to hold meaningful roles and utilize time wisely, and if needs are not met, youth will leave a program (Albright \& Ferrari, 2010).

With the knowledge that youth leave 4-H due to other activities' meeting intrinsic needs, time constraints, and job requirements, educators and volunteers should support youth within these areas. By working closely with other organizations vying for youths' time and developing strategies to assist each other, 4-H members can experience affiliation and success within more than one organization and increase satisfaction and retention (Albright \& Ferrari, 2010; MeeksBaney \& Jones, 2013). Club structure could also increase in flexibility to allow youth participation in other activities (Harder et al., 2005). To address the interests of participating youth, and allow for ownership of project choice, group leaders could conduct a needs assessment of their club membership (Harder et al., 2005). By allowing group input, recognizing its value, and putting results into practice, youth will feel empowered, which can encourage continued participation in 4-H (Harder et al., 2005; Meeks-Baney \& Jones, 2013). STEM curriculum can be tied to current project areas youth are participating in to increase interest and provide some ownership over project choice.

These identified challenges are common across youth development programs. The solutions are complex and may be unique to each local economy and location. Funding may be available through corporate/business partners, grants, fundraisers, or simply user fees and family donations, if appropriate to the situation. STEM educational kits and supplies are often less expensive than livestock, athletic equipment, band instruments or other youth organizational 


\section{4-H STEM Curriculum Challenges: A Delphi Study}

equipment. Youth development STEM instructors must be willing to seek and ask from potential funding sources. STEM Training is often available if sought out.

Organizations could work together to train volunteers and instructors. Partnering with other youth-serving organizations for STEM training may be an appropriate solution. Each organization must recognize its limitations and seek to partner with other organizations to capitalize on specialty and training strengths. Cooperation and communication among competing organizations could strengthen and enhance youth development efforts.

The same enhanced communication and cooperation among youth-serving organizations could allow youth to participate in more activities. We often talk to youth about choices and time limitations. We could switch this conversation to include more youth-serving organizations to adjust scheduling conflicts and cooperation between organizations with an improved focus on youth needs and development. Communication among competing organizations to focus on youth development, youth wants, and needs would be beneficial for all.

Youth development professionals need to consider these challenges in advance of planning and scheduling STEM programming. Advanced planning and communication will enhance the programmatic success and the educational outcomes of STEM education.

\section{Recommendations for Research}

Further research should be conducted to examine the STEM training needs of both educators and volunteers within Oklahoma 4-H and around the country. This research should evaluate current practices and address preferred methods of adult education. Research should also be done on effective evaluation techniques to demonstrate impact with a statewide Extension system. To address youth motivators towards STEM education, research should be conducted to determine preferred subjects and methods of dissemination. Additionally, further research should be done on STEM curriculum challenges of $4-\mathrm{H}$ volunteers. The volunteer panel of the current study did not result in a reliable sample size. However, the qualitative comments provided by this panel were rich in information and ideas for future practice. These ideas should be used to develop a pilot program to improve volunteer training, which could be modeled in other states. These ideas should also be examined further to determine if pursuit of changes in practice is wise. 
Journal of Youth Development | http://jyd.pitt.edu/ | Vol. 15 Issue 5 DOI 10.5195/jyd.2020.823 4-H STEM Curriculum Challenges: A Delphi Study

\section{References}

Albright, M., \& Ferrari, T. (2010). "Push" and "pull" a qualitative study of factors that contribute to older youth leaving the 4-H program. Journal of Youth Development, 5(3). https://jyd.pitt.edu/ojs/jyd/article/view/209

Alexander, J., \& Freel, A. (2018). From the top down: How a statewide listening tour and survey improves 4-H volunteerism. Unpublished manuscript, Arkansas 4-H, University of Arkansas.

Astroth, K. (1985). The challenge of retaining 4-H members. Journal of Extension, 23(3). https://www.joe.org/joe/1985fall/sa4.php

Astroth, K. (2007). Making the best better: 4-H staffing patterns and trends in the largest professional network in the nation. Journal of Youth Development, 2(2). https://jyd.pitt.edu/ojs/jyd/article/view/343

Brady, S. (2015). The Delphi method [uncorrected proof]. http://www.academia.edu/15618774/The Qualitative Delphi_Method

Buriak, P., \& Shinn, G. (1989). Mission, initiatives, and obstacles to research in agricultural education: A national Delphi using external decision-makers. Journal of Agricultural Education, 30(4), 14-23. https://doi.org/10.5032/jae.1989.04014

Cafarella, J., McCullock, A., \& Bell, P. (2017). Why do we need to teach science in elementary school? (Practice Brief No. 43). http://stemteachingtools.org/assets/landscapes/STEM-Teaching-Tool-43Elementary-Science.pdf

Cleveland, L., \& Thompson, J. (2007). Extension education and volunteer service: Assessing motivation and action. Journal of Extension, 45(1). https://www.joe.org/joe/2007february/rb1.php

Culp, K., \& Schwartz, V. J. (1999a). Motivating adult volunteers. Journal of Extension, $3 \pi 1$ ). https://www.joe.org/joe/1999february/rb5.php

Culp, K., \& Schwartz, V. J. (1999b). Recognizing tenured 4-H adult volunteers. Journal of Agricultural Education, 40(2), 38-45. https://doi.org/10.5032/jae.1999.02038

Dalkey, N. C., Rourke, D. L., Lewis, R., \& Snyder, D. (1972). Studies in the quality of life. Lexington Books.

Dillman, D. A., Smyth, J. D., \& Christian, L. M. (2014). Internet, phone, mail, and mixed-mode surveys: The tailored design method ( $4^{\text {th }}$ ed.), John Wiley $\&$ Sons.

Fletcher, A., \& Marchildon, G. (2014). Using the Delphi method qualitative, participatory action research in health leadership. International Journal of Qualitative Methods, 13, 1-18. https://doi.org/10.1177/160940691401300101

4-H National Headquarters. (2011). Mission mandates [Fact Sheet]. https://nifa.usda.gov/sites/default/files/resource/4-H\%20Mission\%20Mandates.pdf 
Journal of Youth Development | http://jyd.pitt.edu/ | Vol. 15 Issue 5 DOI 10.5195/jyd.2020.823 4-H STEM Curriculum Challenges: A Delphi Study

Hanafin, S. (2004). Review on literature on the Delphi technique. Department of Children and Youth Affairs, Ireland. https://www.dcya.gov.ie/documents/publications/Delphi Technique A Literature Review.pdf

Harder, A., Gouldthorpe, J., \& Goodwin, J. (2014). Why work for Extension? An examination of job satisfaction and motivation in a statewide employee retention study. Journal of Extension, 52(3). https://www.joe.org/joe/2014june/a5.php

Harder, A., Lamm, A., Lamm, D., Rose, H., \& Rask,G. (2005). An in-depth look at 4-H enrollment and retention. Journal of Extension, 43(5). https://www.joe.org/joe/2005october/rb4.php

Haugen, H., Stevenson, A., \& Meyer, R. L. (2016). Participant comfort with and application of inquirybased learning: Results from 4-H volunteer training. Journal of Extension, 54(1). https://www.joe.org/joe/2016february/a5.php

Hsu, C., \& Sandford, B. A. (2007). The Delphi technique: Making sense of consensus. Practical Assessment, Research \& Evaluation, 12(10). http://pareonline.net/pdf/v12n10.pdf

Johnson, B., \& Christensen, L. (2014). Educational research (5 $5^{\text {th }}$ ed.). Sage Publications.

Kahler, J. \& Valentine, N. (2011). Stemming the gap. AfterSchool Today. http://techdirections.com Kisiel, J. (2006). Urban teens exploring museums: Science experiences beyond the classroom. The American Biology Teacher, 68(7), 396-401. https://doi.org/10.2307/4452027

Ludwig, B. (1997). Predicting the future: Have you considered using the Delphi methodology? Journal of Extension, 35(5). https://www.joe.org/joe/1997october/tt2.php

Martin, A. G., \& Frick, M. J. (1998). The Delphi technique: An informal history of its use in agricultural education research since 1984. Journal of Agricultural Education, 39(1), 73-79. https://doi.org/10.5032/jae.1998.01073

Mayfield, C. A., Wingenbach, G. J., \& Chalmers, D. R. (2005). Assessing stakeholder needs: Delphi meets the internet. Journal of Extension, 43(3). https://www.joe.org/joe/2005june/iw1.php

Meeks-Baney, C., \& Jones, K. (2013). Whatever it takes: A comparison of youth enrollment trends in the 4-H livestock and non-livestock programs. Journal of Extension, 51(3). https://www.joe.org/joe/2013june/rb2.php

National 4-H Council. (2018). What is 4-H? https://4-h.org/about/what-is-4-h/

National Academy of Sciences (1996). National Science Education Standards. National Academy Press.

National Science Board. (2018). Science and engineering indicators (Policy Companion Brief No. NSB2018-7). https://www.nsf.gov/nsb/sei/companion-brief/NSB-2018-7.pdf

Noyce Foundation. (2013). 4-H science impact: From inception to impact. https://4-h.org/wpcontent/uploads/2016/02/4-H-Science-Initiative-from-Inception-to-Impact-ComprehensiveReport.pdf 
Journal of Youth Development | http://jyd.pitt.edu/ | Vol. 15 Issue 5 DOI 10.5195/jyd.2020.823 4-H STEM Curriculum Challenges: A Delphi Study

Oklahoma 4-H. (2017). Oklahoma 4-H Volunteer Board Constitution.

http://4h.okstate.edu/leadership/copy of state-volunteerboard/ConstitutionandBylaws 2014.docx/

O'Neill, B. (1998). Money talks: Documenting the economic impact of extension personal finance programs. Journal of Extension, 36(5). https://www.joe.org/joe/1998october/a2.php

Pleskac, S. (2009). Wisconsin 4-H volunteers documenting their contributions and volunteer development.

http://www.uwex.edu/ces/4h/resources/mgt/documents/WIVolunteerContributionReport11409fin al.pdf

Ramsey, J. W. (2009). Identifying entry-level skills expected by agricultural industry experts and determining teachers' perceptions on whether they are being learned through students' participation in the supervised agricultural experience component of the secondary agricultural education program: A two-panel Delphi study (Doctoral dissertation). Available from ProQuest Dissertations and theses database. (UMI No. 3390968)

Rice, J. E., Rugg, B., \& Davis, S. (2016). Minnesota 4-H science and agriculture challenge: Infusing agricultural science and engineering concepts into 4-H youth development. Journal of Extension, 54(3). https://www.joe.org/joe/2016june/iw4.php

Riley, D., \& Butler, A. (2012). Priming the pipeline lessons from promising 4-H science programs. https://4-h.org/wp-content/uploads/2016

Rubin, A., \& Babbie, E. R. (2009). Research methods for social work ( $7^{\text {th }}$ ed.). https://www.researchgate.net/publication/237131811 Research Methods for Social Work

Safrit, D., \& Owen, M. (2010). A conceptual model for retaining county Extension program professionals. Journal of Extension, 48(2). https://www.joe.org/joe/2010april/a2.php

Saucier, R., McKim, B., \& Tummons, J. (2012). A delphi approach to the preparation of early career agricultural educators in the curriculum area of agricultural mechanics: Fully qualified and highly motivated or status quo? Journal of Agricultural Education, 53(1), 136-149.

https://doi.org/10.5032/jae.2012.01136

Shafer, L. (2015, November 13). Why science? Usable Knowledge. https://www.gse.harvard.edu/news/uk/15/11/why-science

Shinn, G. C., Wingenbach, G. J., Lindner, J. R., Briers, G. E., \& Baker, M. (2009). Redefining agricultural and extension education as a field of study: Consensus of fifteen engaged international scholars. Journal of International Agricultural and Extension Education, 16(1), 73-88. https://doi.org/10.5191/jiaee.2009.16106

Siegfried, H. (2011). Benefits of the Oklahoma Operation: Military Kids program- a Delphi study (Master's thesis). Available from ProQuest Dissertations and Theses database. (UMI No.1534745) 
Journal of Youth Development | http://jyd.pitt.edu/ | Vol. 15 Issue 5 DOI 10.5195/jyd.2020.823 4-H STEM Curriculum Challenges: A Delphi Study

Sinasky, M., \& Bruce, J. (2007). Volunteers' perceptions of the volunteer management practices of county extension 4-H educators. Journal of Extension, 45(3). https://www.joe.org/joe/2007june/tt5.php

Sitlington, H., \& Coetzer, A. (2014). Using the Delphi technique to support curriculum development. Education + Training, 573). https://doi.org/10.1108/ET-02-2014-0010

Smith, M. H., \& Schmitt-McQuitty, L. (2013). More effective professional development can help 4-H volunteers address need for youth scientific literacy. California Agriculture, 671), 47-53. https://doi.org/10.3733/ca.v067n01p47

Terry, B., Pracht, D., Fogarty, K., Pehlke, T., \& Barnett, L.J. (2013). The similarities between volunteer behavior and consumer behavior: A study of volunteer retention. Journal of Extension, 51(6). https://www.joe.org/joe/2013december/rb2.php

Trapp, J. (2017). Oklahoma Extension: Today and tomorrow [PowerPoint slides]. Oklahoma Cooperative Extension Service.

Turnbull, B. J., Mielke, M., \& Butler, A. (2013). The 4-H science initiative: Summary observations from an evaluation. http://3t61of1t6u3x3af7ir2y91ib.wpengine.netdnacdn.com/wpcontent/uploads/2016/02/4-H-Science-Initiative-PSA-Summary-Report.pdf

U.S. Department of Commerce. (2017, March). STEM jobs: 2017 update (Issue Brief No. 02-17) http://www.esa.doc.gov/sites/default/files/stem-jobs-2017-update.pdf

Vines, K., Cletzer, A., Westfal-Rudd, D., Lambur, M., Hunnings, J., \& Vines, N. (2018). Identifying needs and implementing organizational change to improve retention of early career agents. Journal of Extension, 56 (1). https://www.joe.org/joe/2018february/a2.php

The White House. (2017). President Trump signs memorandum for STEM education funding. https://www.whitehouse.gov/articles/president-trump-signsmemorandum-stem-educationfunding/

Worker, S. (2016). Volunteer educators' influence on youth participation and learning in 4-H STEM learning by design programs (Doctoral dissertation). Available from ProQuest Dissertations and theses database. (UMI No. 10165795).

Workman, J. \& Scheer, S. (2012). Evidence of impact: Examination of evaluation studies published in the journal of extension. Journal of Extension, 50(2). https://www.joe.org/joe/2012april/a1.php

Young, K., Sallee, J., Ramsey, J. \& Cartmell, D. (2019). Using the Delphi technique to determine challenges facing the Oklahoma's 4-H program. Journal of Youth Development 14(3) https://doi.org/10.5195/jyd.2019.740 